\title{
Renal Cell Dysplasia
}

National Cancer Institute

\section{Source}

National Cancer Institute. Renal Cell Dysplasia. NCI Thesaurus. Code C3847.

A finding of congenital malformations in the kidney characterized by the presence of cysts of various sizes, primitive ducts, islands of metaplastic cartilage and undifferentiated mesenchyme, and the absence of cortico-medullary demarcation. 